\title{
Impact of hyper-prolific population generation on the reproduction of sows in multiplication herds
}

\author{
ZDENEK TVRDON ${ }^{1}$ and PETR HUMPOLICEK ${ }^{2}$
}

${ }^{1}$ NAVOS a.s., Kroměříž, Czech Republic, ${ }^{2}$ Tomas Bata University in Zlin, Zlin, Czech Republic

\begin{abstract}
The aim of this study was to evaluate the impact of higher selection pressure used in hyperprolific population on the reproduction of subsequent generations breed in a multiplication herd. Information on 539 litters of 178 ancestors of purebred sows from both hyper-prolific and normal population was included. Higher selection pressure particularly on litter size and teat number was applied in the hyper-prolific population. Differences between total number of piglets born, number of piglets born alive or number of piglets weaned were neither observed on the 1st only nor on the 1st to 5th litters. Likewise, no effect on the age of sows at the first parturition and number of insemination per pregnant had been found. A significant response on selection was determined only for teat number. The descendents of hyper-prolific population had about 0.37 teats more than sows of normal population. The results suggest that to achieve desired litter size in multiplication herds the selection criteria should be revised and higher focus should be put on the prolificacy, particularly on the litter size than on the traits with high heritability like production traits.
\end{abstract}

Keywords: pigs, selection, reproduction, hyper prolific population

\section{Zusammenfassung}

\section{Einfluss hyperfruchtbarer Sauen auf die Reproduktionsleistungen der Nachkommen in einer Vermehrungsherde}

Untersucht wurde der Einfluss eines hohen Selektionsdruckes in einer hyperfruchtbaren Sauenpopulatiuon im Vergleich zu Normalselektion auf das Fruchtbarkeitsgeschehen der Nachkommen in einer Vermehrungsherde über einen Zeitraum von 9 Generationen. Ausgewertet wurden 539 Würfe von 178 Sauen, welche von hyperfruchtbaren oder normal selektierten Sauen abstammten. Die Selektionsmerkmale der hyperfruchtbaren Population waren Merkmale der Wurfgröße und die Zitzenzahl. Bezüglich der Geburtsund Aufzuchtwurfgröße konnten auch bis zum 5. Wurf keine Selektionseffekte nachgewiesen werden. Das betraf auch das Erstwurfalter und die Anzahl notwendiger Besamungen. Lediglich bei den Zitzen ergab sich eine um 0,37 signifikant höhere Zitzenzahl bei Nachkommen der hyperfruchtbaren Population. Es wird geschlussfolgert, dass in hyperfruchtbaren Populationen ein höherer Selektionsdruck besonders bezüglich der Wurfgröße erforderlich ist.

Schlüsselwörter: Schwein, Selektion, Reproduktion, hyperfruchtbare Population 


\section{Introduction}

It has been observed, that up to the middle of the nineties in the past century, the improvements of reproduction traits, mainly of litter size, had no desired effect. The litter size stagnated in some cases even a decrease was observed (KISNER et al. 1995). Various approaches to selection were tested. Nevertheless neither conventional breeding methods nor a modern method based on the molecular genetics has any desired effect. Classical breeding methods are disappointing because of the low heritability and not achieving of intense selection in practice (ROTHSCHILD and BIDANEL 1998). Molecular genetics do not purvey complex information for selection on quantitative traits and have different results in different populations. The effect of many different gene markers or QTL was published recently. One of the most studied are ESR and RYR genes. They were studied, for example, by OMELKA et al. (2006) or WANG et al. (2006). One of the promising ways is combination of both aforementioned methods. Methods for effective selection on litter size have been outlined for example in studies of LAMBERSON et al. (1991), JOHNSON et al. (1999). Recently, the creation of hyper prolific line combined with the selection based on the evaluation of breeding value is believed to be very effective. The molecular approach to hyper prolific line selection is also applied. For example the KERNEROVA et al. (2009) studied the possibility of future classification of gilts to a hyper prolific line based on gene markers. The objective of this study was to estimate the effect of creation of hyper prolific population in breeding herd on the reproductive performance of sows in multiplication herd.

\section{Material and methods}

\section{Population and data collections}

The study is based on the data collected from the commercial multiplication herd. A total of 539 litters which were bred from 178 purebred Large White sows over 5 seasons were studied. All sows included in the study originated from one breeding herd and were breed in one multiplication herd where they were moved at age of 6 months. For all the time the sows were bred under the same conditions.

The litter size was specified by the total number of piglets born (TNB) defined as the number of all fully formed fetuses expelled at farrowing, dead or alive; number of piglets born alive (NBA) defined as the number of piglets alive immediately after birth and by the number of piglets weaned (NW) defined as the number of piglets available on the day post weaning. The prolificacy was specified by the age of sows at the first parturition (AFP), number of insemination per pregnant (NIP) and teat number (TN).

\section{Animal management}

All sows included in the study were bred under the same living conditions. Different pens were used during the reproduction cycle. The inseminations were performed in the individual pen $\left(1.47 \mathrm{~m}^{2}\right)$. When the standing reflex became quiet, the sows were moved to the naturally ventilated house in range of 8 to 4 sows per pen $\left(1.2 \mathrm{~m}^{2}\right)$. In these groups, the sows were reared until 10 days before the supposed parturition day. To parturition, 
the stab lings of $2.1 \mathrm{~m}$ length and $0.7 \mathrm{~m}$ width $(30 \mathrm{~cm}$ area for piglets were separated on both side) with heated mattress $\left(33^{\circ} \mathrm{C}\right)$ were used. Only the total inseminations in the herd were performed by the insemination dose of $80 \mathrm{ml}$ capacity containing 2.5 billions of normal sperm preserved by 7 day diluents. The inseminations were carried out twice a day with $10 \mathrm{~h}$ interval (intervals always with attendance of the boar). All sows were checked for pregnancy at 30th day after insemination by sonograph test. On the 28th day of the piglets' age, the weaning was performed.

The sows were fed twice a day. Throughout the growing period, the gilts have ad libitum access to a standard corn-soybean meal diet containing $13.0 \mathrm{ME} / \mathrm{kg}$ and $9.8 \mathrm{~g}$ of lysine. The corn-soybean diet based on the barley, wheat and soya was used for feeding during the pregnancy of sows (concretely $12.6 \mathrm{ME} / \mathrm{kg}, 160 \mathrm{~g}$ of crude protein and $6.6 \mathrm{~g}$ of lysine.) The diet of similar composition but different parameters $-13.0 \mathrm{ME} / \mathrm{kg}, 200 \mathrm{~g}$ of crude protein and $8 \mathrm{~g}$ of lysine - was given to the nursing sows.

\section{Experimental procedures}

The studied sows originated from one breeding herd where their dams were divided into either hyper-prolific (HP) or normal (N) population. To be incorporated into the HP population, the dams had to meet the following criteria: excellent breeding value for reproduction; at least 12 piglets alive (lifetime productivity from 1st litter); number of teats at least $7 / 8$ and maximal backfat thickness of $12 \mathrm{~mm}$ (determined as a mean from the three measurements: BFT 1 - height at the middle of 2 nd thoracic vertebra, BFT 2 height at the middle of last thoracic vertebra and BFT 3 - height at the middle of 1st sacral vertebra). Dams which did not accomplish these criteria belonged to the $\mathrm{N}$ population.

Breeding values for individual traits were computed for both populations using the same method. The aggregate breeding values were computed separately for both populations using different weight coefficients. In the HP population the aggregate breeding value comprises of $60 \%$ of litter size on the 2 nd and following litters, $30 \%$ of average daily gain and $10 \%$ of lean meat content. In HP populations aggregate breeding values were used for intentional mating.

All dams were mated with the purebred boars of Large White breed but HP sows were mated with boars with excellent breeding values for reproduction ( $>5 \%$ of population). These criteria should provide the descendants with excellent reproduction in multiplication herds.

In total, 63 studied sows were daughters of dams from the HP population and 115 of dams belonged to the $\mathrm{N}$ population. At the age of 6 months, the daughters were moved to the only one multiplication herd where they were mated with the boars of Landrace breed.

\section{Statistical analyses}

The mixed linear models using the procedure REML in SAS (2004) for Windows 9.1.2. were conducted to estimate the differences between the sows of HP and N populations. As very different traits are included in the study, the independent analyses were carried out for each trait. The chosen fixed factors were: the affiliation of the sow to the HP or N populations (Pop); the year and season of litter (YS); type of mating - natural mating of artificial insemination (Mat); and the order of litter (OL). The dam and sire of sow as well 
as the boar that were mated in the multiplication herd were used as the random effects. Furthermore, the back-fat thickness and age at first farrowing was included as linear regression in some models. Individual models are defined in the Table 1 . The analyses of traits of litter size (TNB; NBA; NW) and number of insemination per pregnancy were performed in the 1st and in the 1st to 5th litters independently. The Figure shows the progress across 9 seasons. Each of these seasons covered 6 months.

\section{Results and discussion}

Over the past 50 years the enormous advances in productivity have been achieved through artificial selection. Most of the traits that are selected on are complex quantitative traits, controlled by several genes, along with environmental factors, and the interactions between them. In regard to that, the importance of holistic approach and balance between selection criteria are necessary. Indivisible part of pig industry is crossbreeding in commercial herd joined to breeding in nucleus herd. Genetic improvement in multiplication herd should be taken into consideration during creation of selection criteria in breeding herd. Selection for litter traits is attractive to breeders because lean growth traits, which have been selection objectives for many years, have almost approached optimal point. On the contrary, the level of reproduction, particularly litter size, does not reach the potential maximum. Different approaches increasing litter size had been tested. Nevertheless, none of them had the expected results.

In the present experiment performance emphasis on increasing the litter size, teat number and average daily gain were put on the HP population of sows in contrast to N population in the breeding herd. The effects of ancestor on the litter size on the 1st and 1st to 5 th litter were studied. For the breeding criteria the information from the first litter can be sufficient since high genetic correlations between litters of first parity and later have been confirmed in previous studies e.g. BÖSCH et al. (1999). Although generally the low response on the selection on the litter size is considered, the results of some studies show considerable litter size increasing as an outcome of selection (LAMBERSON et al. 1991, JOHNSON et al. 1999, BOLET et al. 2001). Nevertheless, we did not confirm that the selection on reproduction in the breeding herd has had a significant impact on the litter size in subsequent generation of sows used in the multiplication herd. It can be because of low selection intensity and limited number of sows applied in the experiment. No differences between TNB, NBA or NW were found on the 1st as well as on the 1st to 5th litters (Table 2). Progress in prolificacy is presented in figure where the unbalanced developments are evident in both populations. It may be due to seasonal oscillation. Likewise, no effect on the AFB and NIP had been found.

Teat number is considered as one of the most important factors to evaluate the mothering ability of sows. Evidently, the teat number is more important in the case when this number is lower than the litter size. Nevertheless, KIMA et al. (2005) found the higher number of teat $(\geq 14)$ compared to the teat number in gilts (11-13) increased litter size at birth and at the 21st day of weaning. This is very important in the breed where the teat number limits the number of piglets weaned per year. The present results show, that through direct selection teat number can reach the required level during few generations. 
The main objective of the current study was to find the real impact of the selection on the prolificacy in a multiplication herd through the creation of HP population in the breeding herd. Obtained results cannot be uncritically applied to other populations since many previous studies have affirmed that different results can be estimated in different populations especially in case of production farm. Different results are induced by many factors e.g. genotype environment interactions between a nucleus farm and a farm on production level or effect of crossbreeding (BÖSCH et al. 2000). Different results of studies in breeding and multiplication or production farm has been indicated in the gene markers studies as well. The ESR gene has been considered as one of the most promising gene marker. When this marker started to be studied in different populations the results began to be no homogeneous, for example BUSKE et al. (2006), DRÖGENMÜLLER et al. (1999) DEPUDYPT et al. (1999) or HUMPOLICEK et al. (2006). The study was performed under commercial conditions and the results outlined the usefulness of creation of HP population. The results of the presented study indicate that major accent should be put on the prolificacy, mainly on the litter size. Otherwise the emphasis aimed to improve the production traits should be lesser.

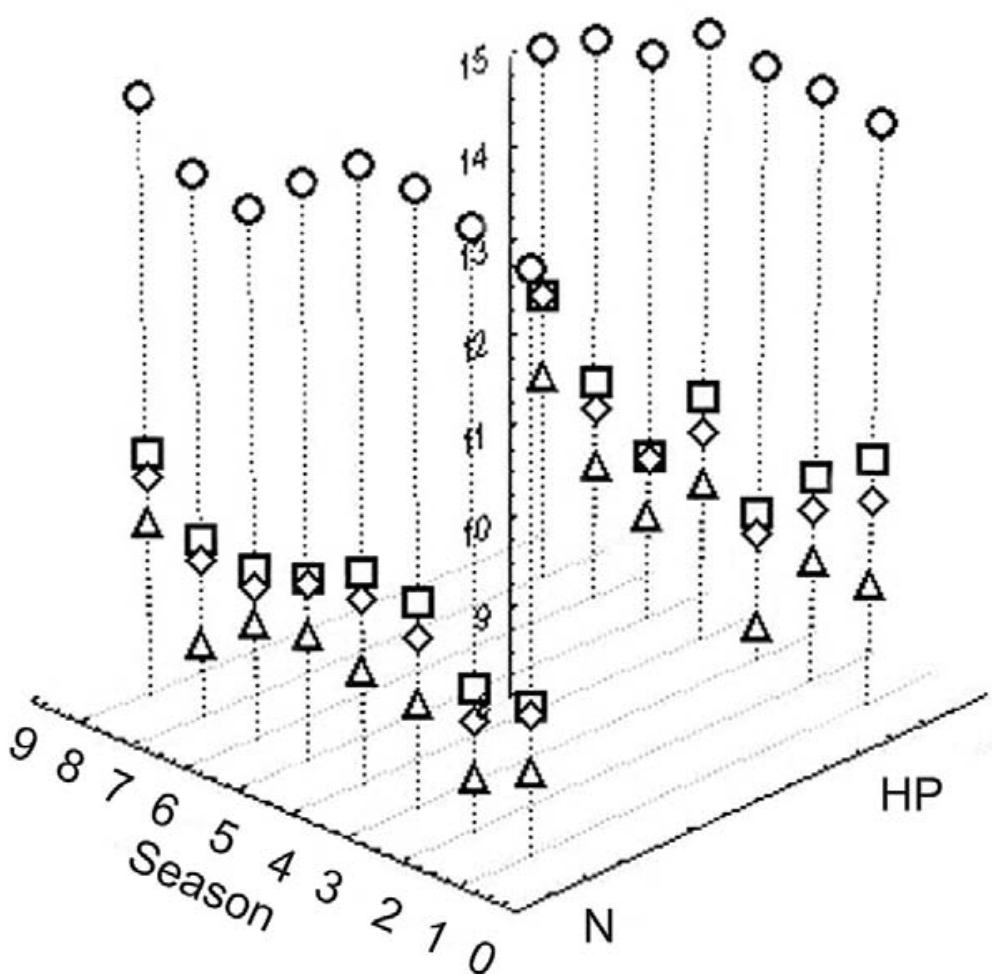

Progress in the sows' prolificacy characterized by the teat number (०), total number of piglets born ( $\square$ ),number of piglets born alive $(\diamond)$ and number of piglets weaned $(\Delta)$ during 9 seasons (every season include 6 months).

Figure

Progress in the sows' prolificacy

Fortschritt bei den untersuchten Merkmalen in 9 Generationen 
Table 1

Specification of used models

Spezifikation des angewandten Modells

\begin{tabular}{lcccccccccc}
\hline & Litters & Pop & YS & Mat & OL & AFF & Dam & Sire & Boar & BF \\
\hline TNB & 1st & F & F & F & - & L & - & - & R & - \\
& 1st-5th & F & F & F & F & L & - & - & R & - \\
NBA & 1st & F & F & F & - & L & - & - & R & - \\
& 1st-5th & F & F & F & F & L & - & - & R & - \\
NW & 1st & F & F & F & - & - & - & - & R & L \\
& 1st-5th & F & F & F & F & - & - & - & R & - \\
AFP & & F & - & - & - & - & R & R & - & - \\
TN & & F & - & - & - & - & R & R & - & - \\
NIP & 1st & F & - & - & - & - & R & R & - & L \\
& 1st-5th & F & - & - & - & - & - & - & - & - \\
\hline
\end{tabular}

$F$ fixed effect, $R$ random effect, $L$ linear regression, TNB total piglets born, NBA piglets born alive, NW number of piglets weaned, AFP age at first parturition, TN teat number, NIP number of insemination per pregnant, BF back-fat thickness, ADG average daily gain, LMC lean meat content, Pop HP or N population, YS year and season of litter, HERD herd of sows, MAT mating or artificial insemination, OL order litter, AFF age at first farrowing, DAM dam of sows, SIRE sire of sows

Table 2

Differences of reproduction between sows of HP or N population Leistungsunterschiede in der hyperfruchtbaren (NP) bzw. der normalen (N) Population

\begin{tabular}{|c|c|c|}
\hline & $\mathrm{N}$ & HP \\
\hline \multicolumn{3}{|c|}{ 1st litters } \\
\hline N (178) & 115 & 63 \\
\hline TNB & $10.88 \pm 0.49$ & $11.69 \pm 0.61$ \\
\hline NBA & $10.22 \pm 0.48$ & $10.97 \pm 0.58$ \\
\hline NW & $10.02 \pm 0.29$ & $10.21 \pm 0.31$ \\
\hline AFB & $369.81 \pm 5.59$ & $368.07 \pm 7.49$ \\
\hline TN & $14.70 \pm 0.10^{A}$ & $15.07 \pm 0.12^{B}$ \\
\hline NIP & $1.06 \pm 0.01$ & $1.08 \pm 0.02$ \\
\hline \multicolumn{3}{|c|}{ 1st-5th litters } \\
\hline N (539) & 353 & 186 \\
\hline TNB & $12.39 \pm 0.38$ & $12.41 \pm 0.41$ \\
\hline NBA & $11.79 \pm 0.36$ & $11.91 \pm 0.38$ \\
\hline NW & $10.42 \pm 0.29$ & $10.61 \pm 0.31$ \\
\hline NIP & $1.07 \pm 0.02$ & $1.09 \pm 0.02$ \\
\hline
\end{tabular}

\section{Acknowledgements}

This study was supported by MSM7088352101.

\section{References}

Bolet G, Bidanel JP, Ollivier L (2001) Selection for litter size in pigs II. Efficiency of closed and open selection lines. Genet Sel Evol 33, 515-28 
Bösch M, Rohe R, Looft H, Kalm E (1999) Selection for litter size in swine. Arch Tierz 42, 555-70

Bösch M, Rohe R, Looft H, Kalm E (2000) Selection on purebred and crossbred performance for litter size in pigs. Arch Tierz 43, 249-62

Buske B, Sternstein L, Reißmann M, Reinecke P, Brockmann G (2006) Analysis of association of GPX5, FUT1 and ESR2 genotypes with litter size in a commercial pig cross population. Arch Tierz 49, 259-68

Chen P, Baas TJ, Mabry JW, Koehler KJ, Dekkers JCM (2003) Genetic parameters and trends for litter traits in US. Yorkshire, Duroc, Hampshire, and Landrace pigs. J Anim Sci 81, 46-53

Chen P, Baas TJ, Mabry JW, Koehler KJ (2003) Genetic correlations between lean growth and litter traits in U.S. Yorkshire, Duroc, Hampshire, and Landrace pigs. J Anim Sci 81, 1700-5

Council Regulation (EEC) No 3220/84 of 13 November 1984 determining the Community scale for grading pig carcases. Official Journal L 301, 20/11/1984, 1-3

Crump RE, Thompshon R, Haley CS, Mercer J (1997) Individual animal model estimates of genetics correlation between performance test and reproduction traits of Landace pigs performance tested in a commercial nucleus herd. Anim Sci 65, 291-8

Depudypt J, De Smet S, Grijspeerdt K, Herman L (1999) Association study of Aval and Pvull polymorphism at the porcine estrogen receptor (ESR) gene, with litter size. Arch Tierz 42 Special Issue, 172-4

Drögenmüller C, Hamann H, Thieven U, Krieter J, Distl O, Harlizius B (1999) Influence of the genome region surrounding the estrogen receptor (ESR) gene on litter size in a German Landrace population. Arch Tierz 42 Special Issue, 175-7

Hermesch S, Luxford BG, Graser HU (2000) Genetic parameters for lean meat yield, meat quality, reproduction and feed efficiency traits for Australian pigs 3. Genetic parameters for reproduction traits and genetic correlations with production, carcass and meat quality traits. Livest Prod Sci 65, 261-70

Holm B, Bakken M, Klemetsdal G, Vangen 0 (2004) Genetic correlations between reproduction and production traits in swine. J Anim Sci 82, 3458-64

Holm B, Bakken M, Vangen O, Rekaya R (2005) Genetic analysis of age at first service return rate, litter size and weaning to first service interval of gilts and sows. J Anim Sci 83, 41-8

Humpolicek P; Urban T, Horak P (2006) Influence of ESR1 and FSHB genes on litter size in Czech Large White sows. Arch Tierz 49, 152-7

Johnson RK, Nielson MK, Casey DS (1999) Responses in ovulation rate, embryonic survival, and litter traits in swine to 14 generations of selection to increase litter size. J Anim Sci 77, 541-57

Kaufmann D, Hofer A, Bidanel JP, Kunzi N (2000) Genetic parameters for individual birth and weaning weight and for litter size of Large White pigs. J. Anim Breed Genet 117, 121-8

Kernerova N, Matoušek V, Čermáková A, Forbelská M (2009) Role of genetic markers in the prediction of classification of Czech Large White gilts to a hyperprolific line. Arch Tierz 52, 40-50

Kima JS, Jinb DI, Leeb JH, Sonc DS, Leed SH, Yib YJ, Park CS (2005) Effects of teat number on litter size in gilts. Anim Reprod Sci 90, 111-6

Kisner V, Mollers B, Brandt H, Glodek P (1995) Analysis of litter performance data from the experimental station Relliehausen for construction of litter quality criteria. I. Influence of fixed effects of breed combination, parity number and birth weight. Arch Tierz 38, 73-86 [in German]

Lamberson WR, Johnson RK, Zimmerman DR, Long TE (1991) Direct response to selection for increased litter size, decreased age at puberty, or random selection following selection for ovulation rate in swine. J Anim Sci 69, 3129-43

Noguera JL, Varona L, Babot D, Estany J (2002) Multivariate analysis of litter size at different parities and production traits in pigs: II. Response to selection for litter size and correlated response to production traits. J Anim Sci 80, 2548-55

Omelka R, Peškovičová D, Martiniaková M, Bauer M, Bauerová M (2006) Effect of the estrogen receptor (ESR) and ryanodine receptor (RYR1) genes on reproductive traits of Slovak Large White, White Meaty and Landrace pigs. Arch Tierz 49, 357-62

Peskovicova D, Wolf J, Groenveld E, Wolfová M (2002) Simultaneous estimation of the covariance structure of traits from field test station test and litter recording in pigs. Livest Prod Sci 77, 155-65

Rosendo A, Druet T, Gogué J, Canario L, Bidanel JP (2007) Correlated responses for litter traits to six generations of selection for ovulation rate or prenatal survival in French Large White pigs. J Anim Sci $85,1615-24$

Rothschild MF, Bidanel JP (1998) Biology and genetics of reproduction, in: Rothschild MF, Ruvinsky A (Eds) The genetics of the pig, CAB International, Wallingford, Oxon, UK, 313-50

SAS (2004) SAS/STAT 9.1 User's guide, SAS Institute Inc., Cary, NC, USA 
See MT, Mabry W, Bertrand JK (1993) Restricted maximum likelihood estimation of variance components from field data for number of pigs born alive. J Anim Sci 71, 2905-9

Serenius T, Sevon-Aimonen ML, Kause A, Mantysaari EA, Maki-Tanila A (2004) Genetic associations of prolificacy with performance, carcass, meat quality, and leg conformation traits in the Finnish Landrace and Large White pig populations. J Anim Sci 82, 2301-6.

Suzuki K, Irie M, Kadowaki H, Shibata T, Kumagai M, Nishida A (2005) Genetic parameter estimates of meat quality traits in Duroc pigs selected for average daily gain, longissimus muscle area, backfat thickness, and intramuscular fat content. J Anim Sci 83, 2058-65.

Wang X, Wang A, Fu J, Lin H (2006) Effects of ESR1, FSHB and RBP4 genes on litter size in a Large White and a Landrace herd. Arch Tierz 49, 64-70

Received 19 January 2009, accepted 19 January 2010.

Corresponding author:

PETR HUMPOLICEK

email: humpolicek@uni.utb.cz

Department of Applied Research, University Institute, Tomas Bata University in Zlin, Nad ovcirnou 4685, 76001 Zlin, Czech Republic 